Baseline

\title{
First detection of pectenotoxin-2 in shellfish associated with an intense spring bloom of Dinophysis acuminata on the central Chilean coast
}

\author{
Patricio A. Díaz ${ }^{\mathrm{a}, *}$, Gonzalo Álvarez ${ }^{\mathrm{b}, \mathrm{c}}$, Miriam Seguel ${ }^{\mathrm{d}}$, Andrés Marín ${ }^{\mathrm{e}}$, Bernd Krock $^{\mathrm{f}}$ \\ ${ }^{a}$ Centro i mar \& CeBiB, Universidad de Los Lagos, Casilla 557, Puerto Montt, Chile \\ ${ }^{\mathrm{b}}$ Facultad de Ciencias del Mar, Departamento de Acuicultura, Universidad Católica del Norte, Coquimbo, Chile \\ ${ }^{\mathrm{c}}$ Centro de Investigación y Desarrollo Tecnológico en Algas (CIDTA), Facultad de Ciencias del Mar, Larrondo 1281, Universidad Católica del Norte, Coquimbo, Chile \\ ${ }^{\mathrm{d}}$ Centro Regional de Análisis de Recursos y Medio Ambiente (CERAM), Universidad Austral de Chile, Los Pinos s/n, Balneario Pelluco, Puerto Montt, Chile

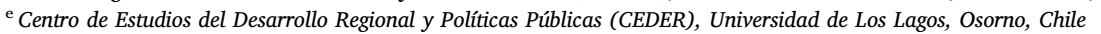 \\ ${ }^{\mathrm{f}}$ Alfred Wegener Institut-Helmholtz Zentrum für Polar- und Meeresforschung, Am Handelshafen 12, 27570 Bremerhaven, Germany
}

\section{A R T I C L E I N F O}

\section{Keywords:}

Dinophysis acuminata

Spring bloom

Lipophilic toxins

Pectenotoxin-2

HAB geographical expansion

\begin{abstract}
A B S T R A C T
Diarrhetic shellfish poisoning (DSP) toxins and pectenotoxins (PTX) produced by endemic species of the genus Dinophysis, mainly $D$. acuta and D. acuminata, pose a big threat to public health, artisanal fisheries and the aquaculture industry in Southern Chile. This work reports the first detection of lipophilic toxins, including pectenotoxin-2 (PTX-2) and gymnodimine-A (GYM-A), in hard razor clam (Tagelus dombeii) associated with an unprecedented spring bloom $-38.4 \times 10^{3}$ cells $\mathrm{L}^{-1}$ in integrated hose sampler $(0-10 \mathrm{~m})$ - of Dinophysis acuminata in coastal waters of central Chile. The socio-economic challenges to small-scale fisheries are discussed. The study points to the pressing need for sound policies to face unexpected HAB event, probably due to biogeographical expansions, with a focus on fisheries management, participation of stakeholders, and development of adaptive capacities.
\end{abstract}

Some dinoflagellates species of the genus Dinophysis produce two groups of lipophilic toxins: the okadaic acid group or diarrhetic toxins (okadaic acid; OA and dinophysistoxins; DTX) and the pectenotoxins (PTXs) (Blanco, 2018). These toxins frequently accumulate in bivalves making them unsafe for human consumption and leading to shellfish closures and restrained marketing of aquaculture products (Blanco et al., 2018). The production of one or both types of toxins and their proportion (toxin profile), as well as toxin content per cell, determine the toxicity of Dinophysis cells. Toxicity and toxin profiles are very variable in species of this genus, and large differences have been found worldwide, even more between strains than between species (Reguera et al., 2014). Consumption of shellfish containing toxins of the OA group cause gastrointestinal symptoms in many parts of the world (Gestal Otero, 2014), but there is no evidence of that PTXs are toxic to humans (Munday, 2014). However, due to their toxicity by intraperitoneal injection in mouse and rat bioassays, these toxins are regulated in the European community, Canada and New Zealand (Vilariño et al., 2015). In Chile, the first record of intoxication by diarrhetic shellfish toxins (DST) dates back to 1970, a year when over 100 people were severely affected by gastrointestinal disorders after eating ribbed mussels (Aulacomya atra) from Reloncaví Sound (Los
Lagos Region). These ribbed mussels were contaminated with lipophilic toxins later associated with a bloom of D. acuta (Guzmán and Campodónico, 1975, 1978; Lembeye et al., 1993). Since then, lipophilic toxin outbreaks produced by endemic species of the genus Dinophysis, mainly $D$. acuta and $D$. acuminata, have occurred in the southernmost regions of the country (Los Lagos, Aysén and Magallanes), posing a threat to public health, artisanal fisheries and the aquaculture industry (Díaz et al., 2011, 2019; Lembeye et al., 1993). In this geographical area, the toxin profiles in shellfish (mainly mytilids, clams and some gastropods) were dominated by OA, DTX-1 and PTX-2 (Contreras and García, 2019; García et al., 2012; Lembeye et al., 1993; Villarroel, 2004; Zhao et al., 1993). Information about toxin profiles and cellular content in Chilean strains of Dinophysis is scarce. Pectenotoxin-2 was the only toxin detected in concentrates of $D$. acuminata from Reloncaví fjord (Goto et al., 2000) and in picked cells of D. cf. ovum (Fux et al., 2011). In addition, OA and DTX-1 were detected in a phytoplankton net-haul sample from Huichas Islands, Aysén Region (Contreras and García, 2019).

The impact of lipophilic toxins in northern Chile has been much less important than in the south. Nevertheless, in 2005 a bloom of Dinophysis caused shellfish closures of the scallop Argopecten purpuratus,

\footnotetext{
* Corresponding author.

E-mail address: patricio.diaz@ulagos.cl (P.A. Díaz).
} 


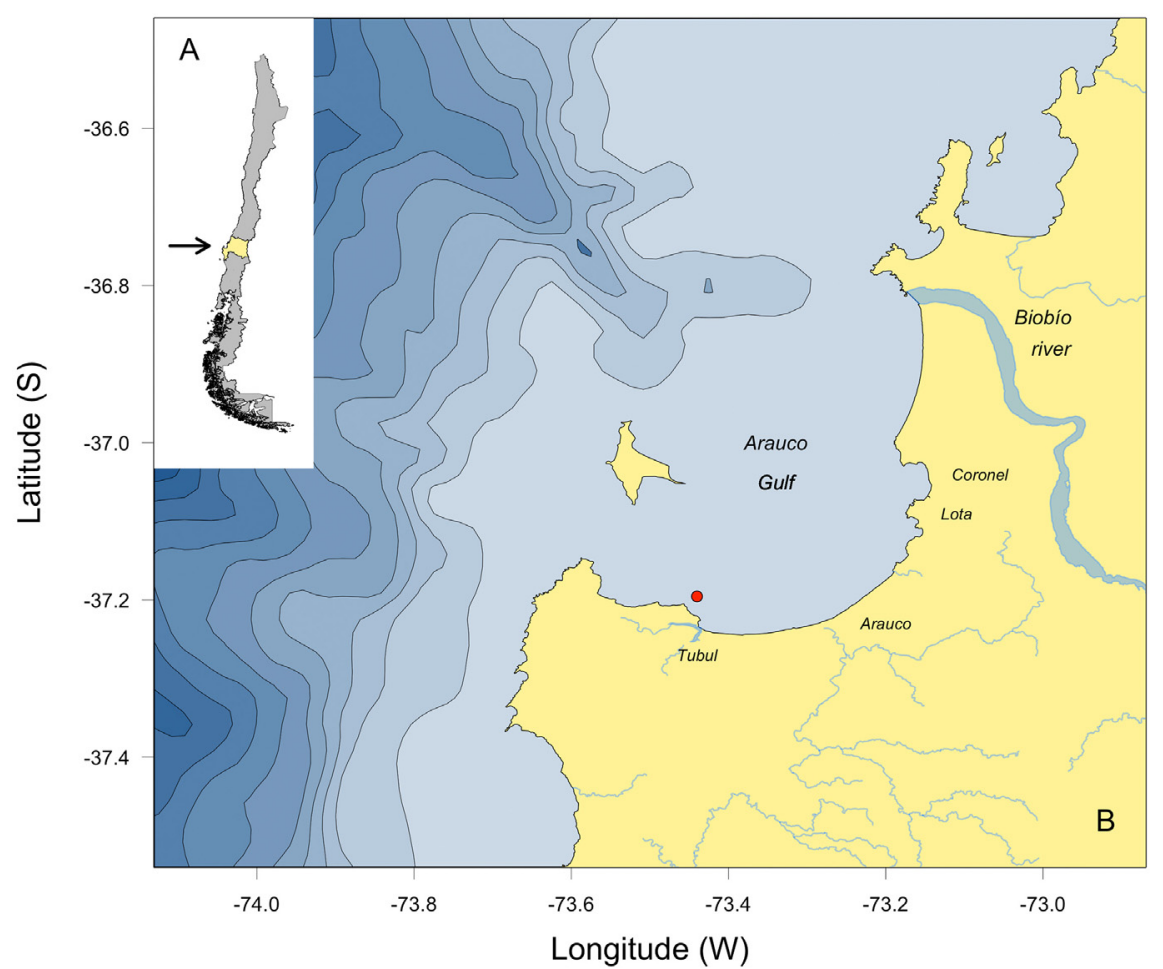

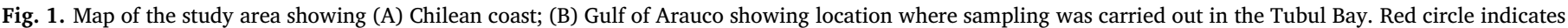
the sampling station. (For interpretation of the references to colour in this figure legend, the reader is referred to the web version of this article.)

one of the most valuable aquaculture species in the north of the country (Blanco et al., 2007). Dinophysis acuminata from that event contained only pectenotoxins (PTX-2 and PTX-11). Likewise, the toxin profiles in the scallop A. purpuratus, the surf clam Mesodesma donacium and the tunicate Pyura chilensis were found to be dominated by PTX-2 and PTX2sa. Toxins of the OA group were never detected (Blanco et al., 2007, 2018).

Benthic resources from the Biobío Region, central Chile, are the second most important in the country after Los Lagos, in gross catches and socioeconomic terms. In 2018, the total catch of benthic resources in Biobio was 88693 tons, of which 7714 tons were bivalves (Sernapesca, 2018). These figures represented 24 and 57\% of national production, respectively. Target bivalve species in the region, with Tubul as the main landing site, include razor clam (Tagelus dombeii; 4591 tons), Giant Patagonian Jackknife (Ensis macha; 1372 tons), and taquilla clams (Mulinia edulis; 1236 tons) and had never been affected by toxic HAB events (Marín et al., 2014). In addition, more than 80000 tons of Jumbo Squid (Dosidicus gigas), recently found to be a potential vector of lipophilic toxins (specifically yessotoxins; Álvarez et al., 2020), were landed the same year by the artisanal fleet in Biobío. Although the contribution of benthic fishery exports to the Biobío's gross domestic product is marginal, its socio-economic importance cannot be underestimated. Benthic fishery activities in Biobío gives direct employment to more than 14000 people including hookah divers and crews operating about 3000 (5-8 m outboard engine) boats, and gleaners (without vessels; Sernapesca, 2018) and indirect jobs in seafood processing plants which rely on the availability of local products. In addition, beach and gastronomic tourism, seafood market stalls, and other complementary services form the basis of local economies in fishing villages and coves (caletas in Spanish; Castilla et al., 1998) along the $\sim 380 \mathrm{~km}$ of the Biobío coast (Marín et al., 2015).

Here we describe the first detection of PTX-2 in Central Chile. Toxins were found in hard razor clams (Tagelus dombeii) associated with an intense spring bloom of $D$. acuminata in Tubul Bay, Gulf of Arauco, Biobío Region, the most important fishing area in the region. The potentially negative impact of toxic $D$. acuminata blooms on artisanal fisheries in Central Chile is discussed.

Tubul Bay, on the southern margin of the Gulf of Arauco, Biobío Region, is the largest bay $(51 \mathrm{~km})$ in central Chile $\left(37^{\circ} \mathrm{S}\right)$ (Fig. 1). This area is at the southernmost limit of the Humboldt Current System, one of the most productive marine ecosystems on earth (Daneri et al., 2000; Thiel et al., 2007). The Gulf of Arauco is one of the three upwelling centres of this system on the Chilean coast. During spring-summer, the presence of colder $\left(<11.5^{\circ} \mathrm{C}\right)$, less oxygenated $\left(<1 \mathrm{mLL}^{-1}\right)$ and saltier ( $\geq 34.5$ ) Equatorial Subsurface Water (ESSW) inside the gulf is an indicator of upwelling pulses (Silva et al., 2009; Sobarzo et al., 2007). The main freshwater input is the Biobío River (annual mean discharge $=899 \mathrm{~m}^{3} \mathrm{~s}^{-1}$ ), which flows into the northern margin of the Gulf forming a brackish water layer at the surface.

Data on Dinophysis cell densities in Tubul Bay before, during and after the lipophilic toxin outbreak were obtained from weekly reports of phytoplankton distribution from the Molluscan Shellfish Safety Programme (PSMB Programa de Sanidad de los Moluscos Bivalvos) of SERNAPESCA (www.sernapesca.cl). In the framework of this programme, weekly water samples for quantitative analyses of phytoplankton are collected with a dividable hose sampler $(0-10 \mathrm{~m})$, a method recommended by the ICES Working Group on Exceptional Algal Blooms (Lindahl, 1986) to monitor harmful species with heterogeneous vertical distribution. Additionally, vertical net ( $20-\mu \mathrm{m}$ mesh) hauls from surface to $20 \mathrm{~m}$ depth were collected for qualitative analysis and identification of species below detection levels in the quantitative analysis. Both kinds of samples were immediately fixed on board with acidic Lugol's iodine solution (Lovegrove, 1960).

Hard razor clams Tagelus dombeii were collected for toxin analysis from a natural shellfish bed by hookah divers, frozen at $-20{ }^{\circ} \mathrm{C}$ and transported to the laboratory.

For quantitative analyses of phytoplankton, $10 \mathrm{~mL}$ of the unconcentrated acidic Lugol's-fixed samples were left to sediment overnight and analysed under an inverted microscope (Olympus CKX41) using the method described in Utermöhl (1958). To enumerate large 

A. glacialis
Dinoflagellates
S. costatum
C. radicans
Other diatoms
C. socialis
Pseudo-nitzschia
T. anguste-lineata
T. rotula
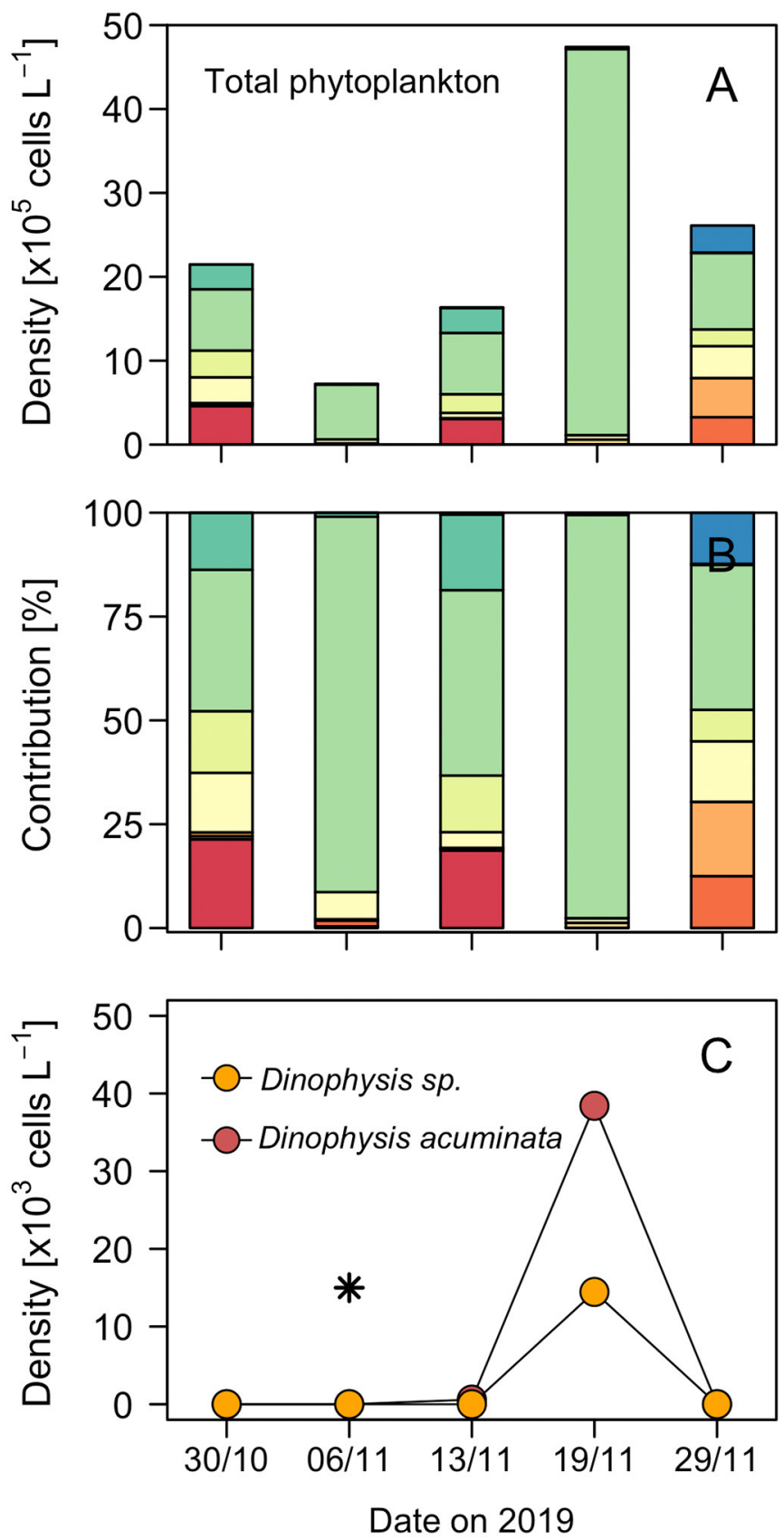

Fig. 2. Temporal distribution of A) Total phytoplankton (cells $\mathrm{L}^{-1}$ ); B) Percentage of contribution (\%); C) Cells density of Dinophysis acuminata and Dinophysis sp. in integrated tube-samples $(0-10 \mathrm{~m})$ collected at Tubul Bay from October 30 to November 29, 2019. Black asterisk indicate the presence of $D$. acuminata cells in vertical net hauls.

less abundant species, such as Dinophysis spp., the whole surface of the chamber was scanned at a magnification of $\times 100$, so that the detection limit was 100 cells $\mathrm{L}^{-1}$.

An aliquot of $4.14 \mathrm{~g}$ of shellfish meat was extracted twice with $5 \mathrm{~mL}$ of $90 \%$ aqueous methanol using a disperser (UltraTurrax, IKA, Stauffen, Germany). After homogenization, both extracts were centrifuged for $10 \mathrm{~min}$ at $3220 \times g$ and supernatants pooled. The extract was defatted three times by dispersion with $8 \mathrm{~mL} \mathrm{n}$-hexane, centrifuged and the $\mathrm{n}$ hexane layer removed. For further purification, the extract was dispersed after addition of $4 \mathrm{~mL}$ deionized water and $8 \mathrm{~mL}$ chloroform and the chloroform layer removed with a glass pipette after centrifugation. The remaining layer was extracted again with $8 \mathrm{~mL}$ chloroform. The combined chloroform extracts were dried over anhydrous sodium sulphate overnight and subsequently concentrated to approximately $1 \mathrm{~mL}$ in a rotary evaporator. The concentrated extract was transferred to a 2$\mathrm{mL}$ centrifugation tube and dried under a gentle stream of nitrogen. The residue was suspended in $200 \mu \mathrm{L}$ methanol by vortexing and centrifuged for $5 \mathrm{~min}$ at $13200 \mathrm{~g}$. The supernatant was transferred to a spin filter $(0.45 \mu \mathrm{m}$, UltraFree, Millipore, Eschborn, Germany) and the residue extracted again with $100 \mu \mathrm{L}$ methanol. The second extract was added to the spin filter and the combined extract filtered prior to analysis. LC-MS/MS analysis was performed as described by Krock et al. (2008).

Microphytoplankton analysis of the weekly monitoring programme (PSMB) revealed a phytoplankton community dominated by diatoms (>98\%) (Fig. 2). On 30 October 2019, this community reached a maximum of $22 \times 10^{5}$ cells $\mathrm{L}^{-1}$ and was dominated by three diatom species: Skeletonema costatum (34.1\%), Asterionellopsis glacialis (21.4\%) and Pseudo-nitzschia spp. (14.8\%) (Fig. 2A). One week later, on 6 November, a significant decline in total phytoplankton cell density $\left(7 \times 10^{5}\right.$ cells $\left.\mathrm{L}^{-1}\right)$, with a clear dominance of the diatom $S$. costatum (90.4\%), was detected (Fig. 2B). The presence of Dinophysis acuminata cells in vertical net hauls was reported at the same time. Over the following two weeks, $D$. acuminata raised reaching values of $6 \times 10^{2}$ cells

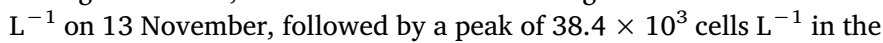
integrated hose samples on 19 November (Fig. 2C). Other Dinophysis spp. (including Dinophysis cf. fortii; Fig. 3), with a maximum of $14.5 \times 10^{3}$ cells $\mathrm{L}^{-1}$, co-occurred with the $D$. acuminata bloom. Despite their high density, Dinophysis cells represented only $1.1 \%$ of a phytoplankton community dominated by $S$. costatum (97.1\%). Ten days later, on 29 November, the phytoplankton density $\left(26.1 \times 10^{5}\right.$ cells $\left.\mathrm{L}^{-1}\right)$, with a dominance of diatoms (S. costatum 34.9\%; Chaetoceros socialis $17.8 \%$; Ch. radicans $12.5 \%)$, declined by half $\left(26.1 \times 10^{5}\right.$ cells $\left.^{-1}\right)$ and Dinophysis cells were no longer detected (Fig. 2).

The unprecedented $D$. acuminata bloom detected in Tubul Bay is comparable to an exceptional early spring bloom of the same species in another upwelling area, the Galician Rías, NW Spain, on the northern limit of the Canary Current System. In late March 2012, a maximum density of $5.3 \times 10^{4}$ cells $\mathrm{L}^{-1}$ of $D$. acuminata in integrated hose samples was recorded in the Rías (Díaz et al., 2013). This was the highest density of $D$. acuminata recorded in the 28-year time series of Galician monitoring. The event was associated with positive anomalies in sea surface temperature (SST) and wind patterns promoting upwelling in the (winter) downwelling season. Likewise, anomalous upwelling patterns affecting the phytoplankton composition (e.g., lower diatoms abundance and lower primary productivity) have been observed in coastal waters of Central Chile (Jacob et al., 2018).

The profiles of Tagelus dombeii revealed only PTX toxins. These included PTX-2, its hydrolysed derivative pectenotoxin-2 seco-acid (PTX2sa) and a putative isomer of PTX-2sa (Fig. 4). PTX-2 levels $\left(2.3 \mu \mathrm{g} \mathrm{kg}^{-1}\right)$ were far below the regulatory limit for this toxin $\left(160 \mu \mathrm{g} \mathrm{kg}^{-1}\right)$ and even the sum of PTX-2, PTX-2sa $\left(5.3 \mu \mathrm{g} \mathrm{kg}^{-1}\right)$ and its putative isomer $\left(17.7 \mu \mathrm{g} \mathrm{kg}^{-1}\right)$ only reached $12 \%$ of the regulatory limit (Fig. 5). The high percentage of PTX seco acids is an indication of a high metabolic capacity of shellfish to transform PTX-2 into PTX-2sa. This enzymatic transformation probably takes places in the gut, during digestion of Dinophysis cells (Blanco, 2018). This process has been described in bivalves such as mussels Perna canaliculus (MacKenzie et al., 2012; Suzuki et al., 2010) and Mytilus edulis (Wilkins et al., 2006); scallops Pecten novaezelandiae (Suzuki et al., 2001) and Argopecten purpuratus (Blanco et al., 2007), and clams Plebidonax deltoides (Burgess and Shaw, 2003) and Mesodesma donacium (Blanco et al., 2018). The PTX-2 levels detected in $T$. dombeii were lower than those reported in 

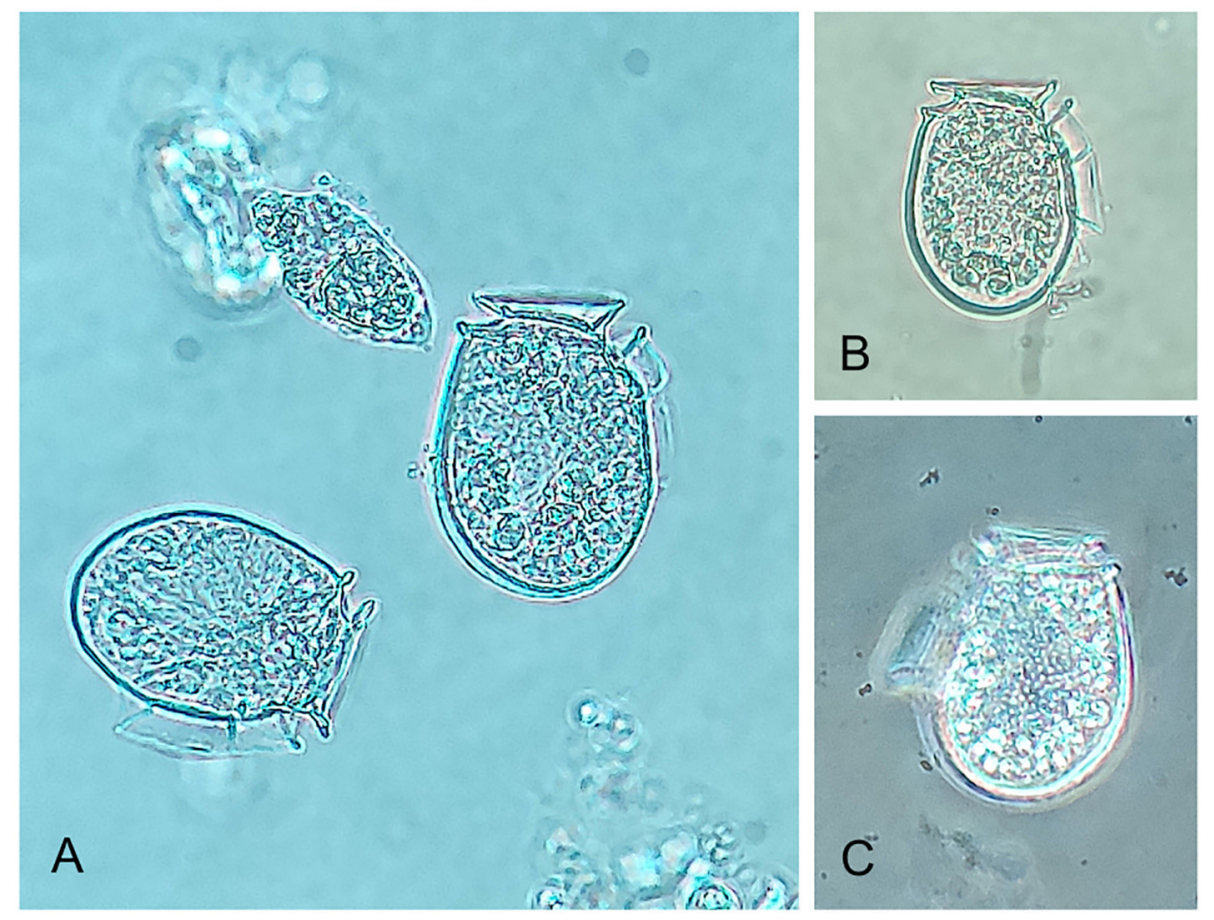

Fig. 3. Micrographs of Dinophysis cells. A-B) Dinophysis acuminata; D) D. forti isolated from the central Chilean coast.

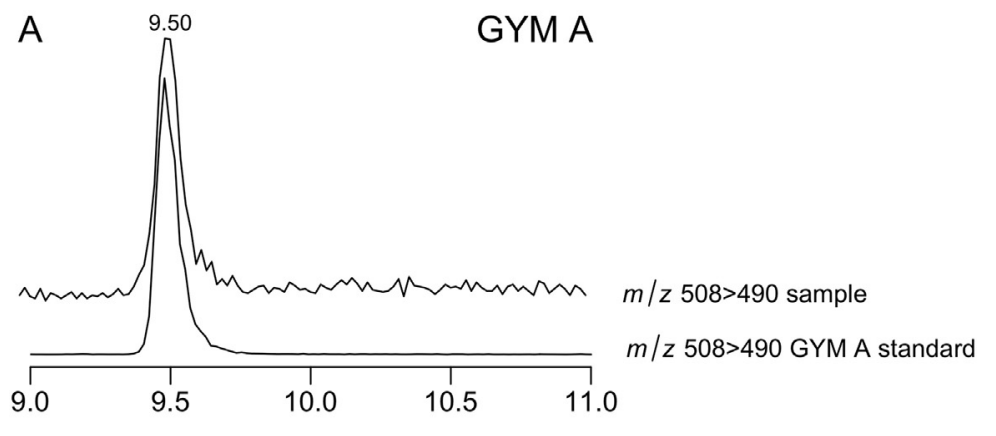

Fig. 4. LC-MS/MS chromatograms of the A) ion transition $m / z 508>490$ of a standard solution of the phycotoxin gymnodimine-A (GYM-A) and an extract of a hard razor clam (Tagelus dombeii) from Tubul Bay; B) ion transitions $m / z 876>213$ (PTX-2) and $894>213$ (PTX-2sa) of a standard solution of PTX-2, a qualified sample containing PTX-2sa and an extract of a hard razor clam (Tagelus dombeii) from Tubul Bay.

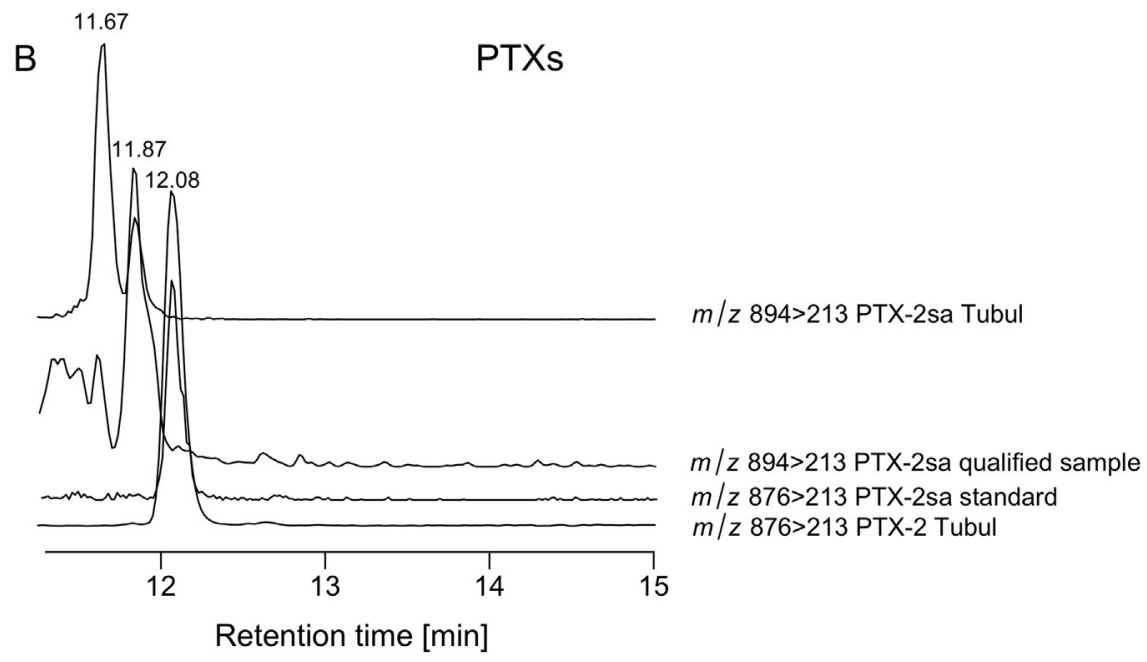

other bivalves in Chile, such as A. purpuratus (52-160 $\mathrm{g} \mathrm{kg}^{-1}$ ) and $M$. donacium (4-90 $\mathrm{u} \mathrm{kg}^{-1}$ ), and similar to those reported in mussels (Semimytilus algosus, $4.7 \mu \mathrm{g} \mathrm{kg}^{-1}$ ) and clams (Mulinia edulis, $3.6 \mu \mathrm{kg}^{-1}$ ) (Blanco, 2018; Blanco et al., 2007). However, it remains unclear if the observed PTX-2 contents in these shellfish species are due to their specific accumulation rates, exposure to different amounts of toxic cells, different depuration rates, or a combination of these parameters. It is noteworthy that no diarrhetic shellfish toxins (OA and DTXs) were detected above the detection limit of $2.7 \times 10^{-4} \mu \mathrm{g} \mathrm{kg}^{-1}$ in shellfish samples from Tubul. Esterified forms of OA and DTXs (DTX-3) resulting from enzymatic transformation by shellfish were not tested for. Nevertheless, the absence of DTXs (detection limit of 


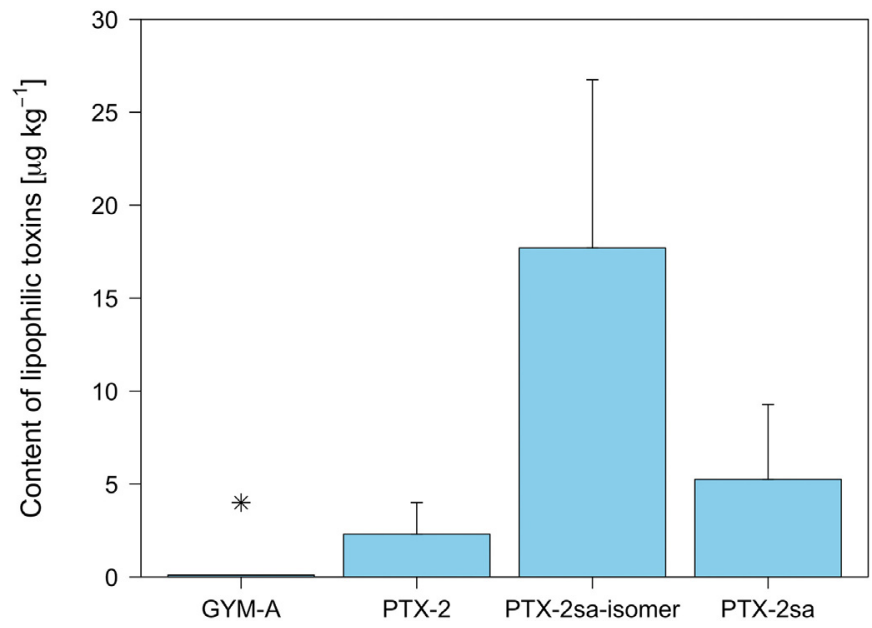

Fig. 5. Lipophilic toxin content $\left(\mu \mathrm{kg}^{-1}\right)$ detected in hard razor clam (Tagelus dombeii) from Tubul Bay on 19 November 2019. GYM-A: gymnodimine-A; PTX2: pectenotoxins-2; PTX-2sa-isomer: pectenotoxin-2 seco-acid isomer; PTX-2sa: pectenotoxin-2 seco-acid. * $0.1 \mu \mathrm{g} \mathrm{kg}^{-1}$.

$2.7 \times 10^{-4} \mu \mathrm{g} \mathrm{kg}^{-1}$ ) makes the detection of DTX-3 very unlikely. These results suggest that the strains of $D$. acuminata and other unidentified Dinophysis species from the central Chilean coast contained only PTX-2, as described for Dinophysis strains from the northern Chilean (Blanco et al., 2007) and Argentinian coasts (Fabro et al., 2016). The PTX profile in T. dombeii was dominated by a yet unknown isomer of PTX2sa. This finding indicates a metabolic process different from the well known hydrolysis of PTX-2 to PTX-2sa, which has not been observed before in other shellfish species. In addition to PTX, a low level of gymnodimine-A (GYM-A) was detected $\left(0.1 \mu \mathrm{g} \mathrm{kg}^{-1}\right)$ in $T$. dombeii samples from Tubul Bay. GYM-A was first associated with Karenia selliformis (reported as Gymnodinium, Seki et al., 1995), but recently Alexandrium ostenfeldii (conspecific with $A$. peruvianum) was also reported as a gymnodimine producer (Van Wagoner et al., 2011; Zurhelle et al., 2018). Due to the low amount in T. dombeii and the absence of potential GYM producers in the phytoplankton community during the incident, the origin of GYM-A in the samples cannot be clarified.

The presence and detection of $D$. acuminata and other Dinophysis species, producers of PTX-2, along the central Chilean coast may result in toxins accumulation in shellfish above the regulatory limits and enforce sanitary closures. This poses a major threat to the sustainability of the small-scale artisanal fishery in the region. In the last decade, in the framework of the Chilean National Programme for detection and control of HABs run by the Ministry of Health, only a few episodes of preliminary DST detection by mouse bioassay have been reported in the local press. But these have generated concern among fishery and health authorities, fishermen, and local entrepreneurs (www.minsal.cl). Smallscale fisheries in the region have been challenged by other environmental disasters in recent years, such as the destructive tsunami of 2010. This has led to discussions on the recovery and adaptive capacity of local fishery organizations (Marín et al., 2015). However, the first detection of lipophilic toxins representes a new threat which may caught fishermen and policy makers unprepared. Associated impacts could include the loss of income for thousands of households, and the increase of illegal fishing and commercialization of unsafe seafood (Andreu-Cazenave et al., 2017; Oyanedel et al., 2018) and, ultimately, social crises (Mascareño et al., 2018). Moreover, recent reports from Los Ríos Region $\left(39^{\circ} \mathrm{S}\right)$ show that the first experience of a toxic $\mathrm{HAB}$ event in that area (Díaz et al., 2019) generated disinformation, uncertainty and mistrust among the affected fishing communities. These results emphasize the need to design and implement sound policies to face unexpected $\mathrm{HAB}$ expansions focused on fisheries management rather than only on sanitary aspects, participation of stakeholders (rather than just authority measures) and prevention rather than cure. Current changes in marine ecosystems, including more frequent, severe and expanding $\mathrm{HAB}$ events, necessitate the creation of adaptive capacities. The capacity of resource users to cope with uncertainty and change relies on, but is not restricted to, the existence of collaborative networks, the inclusion of local ecological knowledge, and the implementation of livelihood diversification strategies (Cinner et al., 2018; Marín, 2019).

\section{CRediT authorship contribution statement}

Patricio A. Díaz:Conceptualization, Methodology, Visualization, Writing - original draft, Writing - review \& editing.Gonzalo Álvarez:Methodology, Investigation, Writing - original draft, Writing - review \& editing.Miriam Seguel:Formal analysis, Methodology, Writing - original draft.Andrés Marín:Investigation, Writing - original draft.Bernd Krock:Formal analysis, Writing - review \& editing.

\section{Declaration of competing interest}

The authors declare that they have no known competing financial interests or personal relationships that could have appeared to influence the work reported in this paper.

\section{Acknowledgements}

We thank the PSMB Monitoring Programme at SERNAPESCA (www. sernapesca.cl) for weekly reports on phytoplankton. We are also grateful to B. Reguera and T. Wyatt for valuable comments and English editing. This study was funded by projects REDI170575 and REDES170101 from the International Cooperation Programme of the CONICYT and partly supported by the Helmholtz-Gemeinschaft Deutscher Forschungszentren through the research program PACES II of the Alfred Wegener Institut-Helmholtz Zentrum für Polar- und Meeresforschung. The authors thank Annegret Müller, AWI for sample processing and Thomas Max, AWI for LC-MS/MS measurements. P.A. Díaz was funded by FONDECYT-CONICYT 11170682, G. Álvarez by FONDEF/CONICYT 2017, IT17F10002 and Andrés Marín by FONDECYT-CONICYT 11171068 in addition to support from the "Center for the Study of Multiple-Drivers on Marine Socio-Ecological Systems", MINECON Chile NC120086. This is a contribution to the Priority Research Area (API) programme on "Disturbances and risks in coastal socio-ecological systems" at the Universidad de Los Lagos.

\section{References}

Álvarez, G., Rengel, J., Álvarez, F., Pino, R., Muñoz, P., Rosales, S., Hevia, V., Araya, M., Díaz, P.A., Rivera, A., Blanco, J., 2020. Mass mortality of marine invertebrates associated by the presence of yessotoxins in northern Chile. Harmful Algae News 64, 6-7.

Andreu-Cazenave, M., Subida, M.D., Fernandez, M., 2017. Exploitation rates of two benthic resources across management regimes in central Chile: evidence of illegal fishing in artisanal fisheries operating in open access areas. PLoS One 12, e0180012.

Blanco, J., 2018. Accumulation of Dinophysis toxins in bivalve molluscs. Toxins 10, 453.

Blanco, J., Álvarez, G., Uribe, E., 2007. Identification of pectenotoxins in plankton, filter feeders, and isolated cells of a Dinophysis acuminata with an atypical toxin profile, from Chile. Toxicon 49, 710-716.

Blanco, J., Álvarez, G., Rengel, J., Diaz, R., Marino, C., Martin, H., Uribe, E., 2018. Accumulation and biotransformation of Dinophysis toxins by the surf clam Mesodesma donacium. Toxins 10, 314 .

Burgess, V., Shaw, G., 2003. Investigations Into the Toxicology of Pectenotoxin-2-seco Acid and 7-Epi pectenotoxin 2-seco Acid to Aid in a Health Risk Assessment for the Consumption of Shellfish Contaminated With These Shellfish Toxins in Australia; Report on Project No. 2001/258. Fisheries Research and Development Corporation, Canberra, Australia (ISBN 0975025910. 54 pp.).

Castilla, J.C., Manríquez, P., Álvarado, J., Rosson, A., Pino, C., Espoz, C., Soto, R., Oliva, D., Defeo, O., 1998. Artisanal "caletas" as units of production and co-managers of benthic invertebrates in Chile. Can. J. Fish. Aquat. Sci. 125, 407-413.

Cinner, J.E., Adger, W.N., Allison, E.H., Barnes, M.L., Brown, K., Cohen, P.J., Gelcich, S., Hicks, C.C., Hughes, T.P., Lau, J., Marshall, N.A., Morrison, T.H., 2018. Building 
adaptive capacity to climate change in tropical coastal communities. Nature Clim. Change 8, 117-123.

Contreras, H.R., García, C., 2019. Inter-species variability of okadaic acid group toxicity in relation to the content of fatty acids detected in different marine vectors. Food Addit. Contam. Part A 36, 464-482.

Daneri, G., Dellarossa, V., Quiñones, R., Jacob, B., Montero, P., Ulloa, O., 2000. Primary production and community respiration in the Humboldt Current System off Chile and associated oceanic areas. Mar. Ecol. Prog. Ser. 197, 41-49.

Díaz, P., Molinet, C., Cáceres, M., Valle-Levinson, A., 2011. Seasonal and intratidal distribution of Dinophysis spp in a Chilean fjord. Harmful Algae 10, 155-164.

Díaz, P.A., Reguera, B., Ruiz-Villarreal, M., Pazos, Y., Velo-Suárez, L., Berger, H., Sourisseau, M., 2013. Climate variability and oceanographic settings associated with interannual variability in the initiation of Dinophysis acuminata blooms. Mar. Drugs 11, 2964-2981.

Díaz, P.A., Álvarez, A., Varela, D., Pérez-Santos, I., Díaz, M., Molinet, C., Seguel, M., Aguilera-Belmonte, A., Guzmán, L., Uribe, E., Rengel, J., Hernández, C., Segura, C., Figueroa, R.I., 2019. Impacts of harmful algal blooms on the aquaculture industry: Chile as a case study. Perspectives in Phycology. https://doi.org/10.1127/pip/2019/ 0081.

Fabro, E., Almandoz, G.O., Ferrario, M., Tillmann, U., Cembella, A., Krock, B., 2016. Distribution of Dinophysis species and their association with lipophilic phycotoxins in plankton from the Argentine Sea. Harmful Algae 59, 31-41.

Fux, E., Smith, J.L., Tong, M., Guzmán, L., Anderson, D.M., 2011. Toxin profiles of five geographical isolates of Dinophysis spp. from North and South America. Toxicon 57, 275-287.

García, C., Rodriguez-Unda, N., Contreras, C., Barriga, A., Lagos, N., 2012. Lipophilic toxin profiles detected in farmed and benthic mussels populations from the most relevant production zones in Southern Chile. Food Addit. Contam. Part A 29, 1011-1020.

Gestal Otero, J.J., 2014. Epidemiology of marine toxins. In: Botana, L.M. (Ed.), Seafood and Freshwater Toxins. Physiology, Pharmacology and Detection, 3rd ed. CRC Press, Taylor and Francis Group, Boca Ratón, FL, USA, pp. 123-195.

Goto, H., Igarashi, T., Watai, M., Yasumoto, T., Villarroel, O., Lembeye, G., Noren, F., Gisselson, G., Graneli, E., 2000. Worldwide occurrence of pectenotoxins and yessotoxins in shellfish and phytoplankton. In: Hallegraeff, G.M., Blackburn, S.I., Bolch, C.J., Lewis, R.J. (Eds.), Harmful Algal Blooms 2000, Proceedings of the IX International Conference on Harmful Alga Blooms. Intergovernmental Oceanographic Commission of UNESCO, Hobart, Tasmania, Australia, pp. 49.

Guzmán, L., Campodónico, I., 1975. Marea roja en la región de Magallanes Publ. Inst. Pat. Ser. Mon. vol. 9. pp. 44.

Guzmán, L., Campodónico, I., 1978. Mareas rojas en Chile. Interciencia 3, 144-151.

Jacob, B.G., Tapia, F.J., Quiñones, R.A., Montes, R., Sobarzo, M., Schneider, W., Daneri, G., Morales, C., Montero, P., Gonzáles, H.E., 2018. Major changes in diatom abundance, productivity, and net community metabolism in a windier and dryer coastal climate in the southern Humboldt Current. Prog. Oceanogr. 168, 196-209.

Krock, B., Tillmann, U., John, U., Cembella, A.D., 2008. LC-MS-MS aboard ship: tandem mass spectrometry in the search for phycotoxins and novel toxigenic plankton from the North Sea. Anal. Bioanal. Chem. 392, 797-803.

Lembeye, G., Yasumoto, T., Zhao, J., Fernández, R., 1993. DSP outbreak in Chilean fjords. In: Smayda, T.J., Shimizu, Y. (Eds.), Toxic Phytoplankton Blooms in the Sea. Elsevier, Ámsterdam, pp. 525-529.

Lindahl, O., 1986. A dividable hose for phytoplankton sampling. Report of the working group on phytoplankton and management of their effects. In: International Council for the Exploration of the Sea, C.M.1986/L: 1926, Annex 1983.

Lovegrove, T., 1960. An improved form of sedimentation apparatus for use with an inverted microscope. J. Cons. Int. Explor. Mer 25, 279-284.

MacKenzie, L., Selwood, A.I., Marshall, C., Baba, T., 2012. Isolation and characterization of an enzyme from the Greenshell ${ }^{\mathrm{TM}}$ mussel Perna canaliculus that hydrolyses pectenotoxins and esters of okadaic acid. Toxicon 60, 406-419.

Marín, A., 2019. Adaptive capacity to coastal disasters: challenges and lessons from smallscale fishing communities in Central-Southern Chile. In: Silvia, S., BarraganPaladines, M.J., Chuenpagdee, R. (Eds.), Viability and Sustainability of Small-Scale Fisheries in Latin America and The Caribbean. Springer, Cham, pp. 51-78.

Marín, A., Gelcich, S., Castilla, J.C., 2014. Ecosystem services and abrupt transformations in a coastal wetland social-ecological system: Tubul-Raqui after the 2010 earthquake in Chile. Ecol. Soc. 19, 2.

Marín, A., Bodin, Ö., Gelcich, S., Crona, B., 2015. Social capital in post-disaster recovery trajectories: insights from a longitudinal study of tsunami-impacted small-scale fisher organizations in Chile. Global Environ. Chang. 35, 450-462.

Mascareño, A., Cordero, R., Azócar, G., Billi, M., Henríquez, P.A., Ruz, G.A., 2018. Controversies in social-ecological systems: lessons from a major red tide crisis on Chiloe Island, Chile. Ecol. Soc. 23, 15.

Munday, R., 2014. Toxicology of seafood toxins: a critical review. In: Botana, M.L. (Ed.), Seafood and Freshwater Toxins, Pharmacology, Physiology and Detection. CRC Press, Boca Raton, FL, USA, pp. 197-290.

Oyanedel, R., Keim, A., Castilla, J.C., Gelcich, S., 2018. Illegal fishing and territorial user rights in Chile. Conserv. Biol. 32, 619-627.

Reguera, B., Riobó, P., Rodríguez, F., Díaz, P.A., Pizarro, G., Paz, B., Franco, J.M., Blanco, J., 2014. Dinophysis toxins: causative organisms, distribution and fate in shellfish. Mar. Drugs 12, 394-461.

Seki, T., Satake, M., MacKenzie, A.L., Kaspar, H.F., Yasumoto, T., 1995. Gymnodimine, a new marine toxin of unprecedented structure isolated from New Zealand oysters and the dinoflagellate, Gymnodinium sp. Tetrahedron Lett. 36, 7093-7096.

Sernapesca, 2018. Anuario Estadistico de Pesca. Servicio Nacional de Pesca, Valparaíso.

Silva, N., Rojas, N., Fedel, A., 2009. Water masses in the Humboldt Current System: properties, distribution, and the nitrate deficit as a chemical water mass tracer for equatorial subsurface water off Chile. Deep Sea Res. II 56, 1004-1020.

Sobarzo, M., Bravo, L., Donoso, D., Garcés-Vargas, J., Schneider, W., 2007. Coastal upwelling and seasonal cycles that influence the water column over the continental shelf off central Chile. Prog. Oceanogr. 75, 363-382.

Suzuki, T., Mackenzie, L., Stirling, D., Adamson, J., 2001. Conversion of pectenotoxin-2 to pectenotoxin-2 seco acid in the New Zealand scallop, Pecten novaezelandiae. Fish. Sci. 67, 506-510.

Suzuki, T., Mackenzie, L., Stirling, D., Adamson, J., 2010. Pectenotoxin-2 seco acid: a toxin converted from pectenotoxin-2 by the New Zealand Greenshell mussel, Perna canaliculus. Toxicon 39, 507-514.

Thiel, M., Macaya, E.C., Arntz, W.E., H. B, Brokordt, K., Camus, P.A., Castilla, J.C., Castro, L.R., Cortes, M., Dumont, C.P., Escribano, R., Fernandez, M., Gajardo, J.A., Gaymer, C.F., Gomez, I., Gonzalez, A.E., Gonzalez, H.E., Haye, P.A., Illanes, J.E., Iriarte, J.L., Lancellotti, D.A., Luna-Jorquera, G., Luxordo, C., Manriquez, P.H., Marin, V., Muños, P., Navarrete, S.A., Perez, E., Poulin, E., Sellanes, J., Sepulveda, H.H., Stotz, W., Tala, F., Thomas, A., Vargas, C.A., Vasquez, J.A., Vega, J.M.A., 2007. The Humboldt current system of northern and central Chile. Oceanogr. Mar. Biol. Annu. Rev. 45, 195-345.

Utermöhl, H., 1958. Zur Vervollkomnung der quantitativen phytoplankton-Methodik. Mitt. Int. Ver. Limnol. 9, 1-38.

Van Wagoner, R.M., Misner, I., Tomas, C., Wright, J.L.C., 2011. Occurrence of 12-methylgymnodimine in a spirolide-producing dinoflagellate Alexandrium peruvianum and the biogenetic implications. Tetrahedron Lett. 52, 4243-4246.

Vilariño, N., Louzao, M.C., Fraga, M., Botana, A., 2015. From science to policy: dynamic adaptation of legal regulations on aquatic biotoxins. In: Botana, L.M., Louzano, C., Vilariño, N. (Eds.), Climate Change and Marine and Freshwater Toxins. de Gruyter, Berlin, pp. 441-482.

Villarroel, O., 2004. Detección de toxina paralizante, diarreica y amnésica en mariscos de la XI región por Cromatografía de Alta Resolución (HPLC) y bioensayo de ratón. Cienc. Tecnol. Mar. 27, 33-42.

Wilkins, A.L., Rehmann, N., Torgersen, T., Rundberget, T., Keogh, M., Petersen, D., Hess, P., Rise, F., Miles, C.O., 2006. Identification of fatty acid esters of pectenotoxin-2 seco acid in blue mussels (Mytilus edulis) from Ireland. J. Agric. Food Chem. 54, 5672-5678.

Zhao, J., Lembeye, G., Cenci, G., Wall, B., Yasumoto, T., 1993. Determination of okadaic acid and dinophysistoxin-1 in mussels from Chile, Italy and Ireland. In: Smayda, T.J., Shimizu, Y. (Eds.), Toxic Phytoplankton Blooms in the Sea. Elsevier, Amsterdam, pp. 587-592.

Zurhelle, C., Nieva, J., Tillmann, U., Harder, T., Krock, B., Tebben, J., 2018. Identification of novel gymnodimines and spirolides from the marine dinoflagellate Alexandrium ostenfeldii. Mar. Drugs 16, 446. 